\title{
VOLUME 41 NUMBER 4
}

JULY 2009

JOURNAL OF<smiles>[GeH3]O[GeH3]</smiles>

SCIENCE 


\title{
Official Journal of the Biosocial Society
}

\author{
EDITOR \\ Professor C. G. N. Mascie-Taylor \\ Department of Biological Anthropology, University of Cambridge, \\ Downing Street, Cambridge CB2 3DZ, UK
}

\begin{abstract}
ASSOCIATE EDITOR
\end{abstract}
Miss C. M. Gallimore
BOOK REVIEW EDITOR

Professor S. J. Ulijaszek

\author{
EDITORIAL BOARD \\ G. R. Bentley Durham University, UK \\ G. Biondi University of L'Aquila, Italy \\ A. H. Bittles Edith Cowan University, Perth, Australia \\ J. L. Boldsen University of Odense, Denmark \\ P. T. Ellison Harvard University, USA \\ E. Godina Moscow State University, Russia \\ G. A. Harrison University of Oxford, UK \\ G. Hauser University of Vienna, Austria \\ A. G. Hill Harvard University, USA \\ P. R. A. Hinde University of Southampton, UK \\ T. Inaoka Saga University, Japan \\ B. Janowitz Family Health International, North Carolina, USA \\ K. Moji Research Institute for Humanity and Nature, Kyoto, Japan \\ R. Ohtsuka Japan Wildlife Research Center, Japan \\ M. Parker Brunel University, UK \\ D. M. Potts University of California, Berkeley, USA \\ D. F. Roberts University of Newcastle upon Tyne, UK \\ L. Rosetta Centre National de la Recherche Scientifique, Paris, France \\ L. H. Schmitt University of Western Australia, Perth, Australia \\ I. Timaeus University of London, UK \\ S. J. Ulijaszek University of Oxford, UK
}

\section{COPYING}

This journal is registered with the Copyright Clearance Center, 222 Rosewood Drive, Danvers, MA 01923. Organizations in the USA who are also registered with the C.C.C. may therefore copy material (beyond the limits permitted by sections 107 and 108 of US copyright law) subject to payment to C.C.C. of the per-copy fee of $\$ 16.00$. This consent does not extend to multiple copying for promotional or commercial purposes. Code 0021-9320/2005 \$16.00.

ISI Tear Sheet Service, 3501 Market Street, Philadelphia, Pennsylvania 19104, USA, is authorized to supply single copies of separate articles for private use only. Organizations authorized by the Copyright Licensing Agency may also copy material subject to the usual conditions.

For all other use, permission should be sought from Cambridge or the American Branch of Cambridge University Press.

\section{SUBSCRIPTIONS}

Journal of Biosocial Science (ISSN print 0021-9320 electronic 1469-7599) is published annually in one volume of six parts in January, March, May, July, September and November.

The subscription price (excluding VAT) of volume 41, 2009, is £296 Institutions print and electronic, (USA, Canada and Mexico US\$536) post free institutions electronic only $£ 250 / \$ 438$; single parts cost $£ 52$ net (USA, Canada and Mexico US\$87) plus postage. Back volumes are also available. EU subscribers (outside the UK) who are not registered for VAT should add VAT at their country's rate. VAT registered subscribers should provide their VAT registration number. Orders, which must be accompanied by payment, may be sent to any bookseller, subscription agent or to the publisher: Cambridge University Press, The Edinburgh Building, Shaftesbury Road, Cambridge CB2 8RU, or in the USA, Canada and Mexico to Cambridge University Press, Journals Department, Journals Fulfillment Department, 100 Brook Hill Drive, West Nyack, New York, 10994-2133. Japanese prices for institutions are available from Kinokuniya Company Ltd, P.O. Box 55, Chitose, Tokyo 156, Japan. Prices include delivery by air. Application to mail at Periodicals Postage Rates is paid at New York, $\mathrm{NY}$, and at additional mailing offices.

POSTMASTER: send address changes in USA, Canada and Mexico to Journal of Biosocial Science, Cambridge University Press, Journals Fulfillment Department, 100 Brook Hill Drive, West Nyack, New York, 10994-2133.

Information on Journal of Biosocial Science can be accessed via journals.cambridge.org/JBS, and all other Cambridge journals can be accessed via http://www.cambridge.org 